\title{
Does country governance foster revenue efficiency of Islamic and conventional banks in GCC countries?
}

\begin{abstract}
Purpose

The purpose of this paper is to provide new empirical evidence on the impact of country governance on the revenue efficiency of Islamic and conventional banks. The empirical analysis is confined to Islamic and conventional banks operating in the Gulf Cooperation Council (GCC) countries banking sectors during the period of 2007-2011.

\section{Design/methodology/approach}

The analysis comprises two main stages. In the first stage, the authors employ the data envelopment analysis (DEA) method to compute the revenue efficiency of Islamic and conventional banks. The authors then used the multivariate panel regression analysis with the ordinary least square and generalized method of moments as an estimation method to investigate the potential determinants and the effect of country governance on the revenue efficiency.
\end{abstract}

\section{Findings}

The empirical findings indicate that greater voice and accountability, government effectiveness, and rule of law enhance the revenue efficiency of both Islamic and conventional banks. The authors find that regulatory quality exerts positive influence on Islamic banks, while the impact of political stability and control of corruption enhances the revenue efficiency of conventional banks.

\section{Originality/value}

The study on the specific revenue efficiency concept of Islamic and conventional banking is still in its formative stage. In regards, majority of the studies that examined the effect of governance on bank efficiency have focused more on the corporate or bank governance that affects the governance within the institution. Thus, to the best of the knowledge, no study has been done to address the effect of country governance on the revenue efficiency of Islamic and conventional banks specifically on the GCC countries.

Keyword: Data envelopment analysis; Revenue efficiency; Country governance; Gulf Cooperation Council 